\title{
The Northern BackCountry PATrol Cabins of Grand Teton National PARK
}

\author{
-

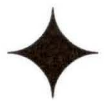 \\ James A. PRitchard DEPARTMENT of NATURAl ResourCes, ECOlOGy \& MANAGEMENT \\ IOWA STATE UNIVERSITY $\downarrow$ AMES \\ KATHERINE LONGFIELD $\uparrow$ WESTERN CENTER FOR HISTORIC PRESERVATION \\ GRAND TETON NATIONAL PARK
}

\section{$\downarrow \quad$ INTRODUCTION}

During the summer of 2008 , this study investigated the patrol cabin located at the lower end of Berry Creek (at the north end of Jackson Lake, in Grand Teton National Park) for possible inclusion on the National Register of Historic Places. James Pritchard conducted research at the National Archives near College Park, Maryland (hereafter NARA), and in records at Grand Teton National Park (GTNP), while Katherine Longfield of the Western Center for Historic Preservation, Grand Teton National Park (WCHPGTNP) wrote the resulting proposal for the National Register. Secondly, the study began to look into the rumor that Olaus Murie built two small cabins in remote parts of the North District, at Upper Berry and Moose Basin. Finally, the project sought to set these cabins into the wider context of park history.

\section{The Trail System and Need for Cabins}

The backcountry trail system was originally proposed by Fritiof M. Fryxell in 1929 as an integral part of the interpretation plan for the newly established Grand Teton National Park. From the beginning, Fryxell and park administrators envisioned building cabins to support trail construction crews, for wildlife protective patrols, and to place fire control personnel in remote areas.

In 1938, GTNP Superintendent Guy D. Edwards advised the NPS regional director that housing trail crews in tents was ineffective in "a Park of this nature, which is subject to very heavy snowfall, periods of heavy rain" and a short tourist season. The superintendent advocated for patrol cabins to house the trail crews, allowing more time on the trail, enhanced access, and increased safety. Secondly, cabins were seen as an absolute necessity to carry out patrols aimed at preventing poaching of wildlife in the park. During the $1930 \mathrm{~s}$, hunters pursued sheep near the western boundary, and trappers sought marten and beaver in Granite Creek and elsewhere. Edwards wrote that the park was accessible to trappers coming in from the west side, and "if the area cannot be reached from the east side by the protection force trapping continues the entire winter." As late as 1951, the superintendent noted that "poaching has been carried on all summer in the Berry Creek country and the pressure of work has prevented patrols in this area." (Boxes 1053 \& 200, NARA). Three patrol cabins built on the western edge of the valley floor (Moran Bay, Leigh Lake, and Hot Springs cabins) were often referred to as "snowshoe cabins," as they were located a winter day's travel apart. These cabins may have provided winter patrols a link to the remote North District and the cabin at Berry Creek.

\section{Berry Creek and Land Transfers}

The Teton Forest Reserve was established in 1897 by President Grover Cleveland's executive order, encompassing the mouth of Berry Creek. Official jurisdiction of the cabin site, if not its actual use, took a twist when the Bureau of Reclamation withdrew a parcel at the mouth of Berry Creek on July 10, 1903, in 
conjunction with construction of the Jackson Lake dam. Workers floated many logs across Jackson Lake to provide materials used in dam construction. It remains unclear exactly when that withdrawal was revoked. Congress established Grand Teton National Park in February 1929. At that time, however, the park boundaries did not extend as far north as the Owl Creek or Berry Creek drainages. A 1938 memo from the park superintendent notes "One other cabin at the north end of the Park belonging to the Forest Service is used by the Park during the winter" (Box 1053 NARA). In 1943, establishment of the Jackson Hole National Monument transferred 99,345 acres from Teton National Forest, including the general area around the Berry Creek cabin. In 1950, the monument was incorporated into Grand Teton National Park (Wilson 2004).

\section{The Lower Berry Cabin}

Although the northwest portion of GTNP is considered relatively remote and does not see the high levels of visitation of the South District, from prehistoric times some travelers passing from Jackson's Hole into Idaho have traveled westward up Berry Creek. Around 1900, A.J. Berry lived near the mouth of Berry Creek, which was named for him. This designation first appeared on a 1899 Grand Teton Quadrangle map. Like a few others in this remote drainage, he made a living by trapping or mining. If he built a cabin, it remains unclear what happened to it.

The cabin at Berry Creek today presents a conundrum in architectural history. It does not exhibit the classic rustic style employed on some other cabins in GTNP. Did the US Forest Service build it? It does not fit standard USFS cabin plans of the 1920s, yet resembles cabins built before the New Deal. One of the walls incorporates a 6-pane window, commonly used on USFS buildings and known as "barn-sash," yet another side of the cabin exhibits a 9-pane window, which was not common on USFS structures. A careful search through several archives uncovered clues resulting in the following account.

Evidence points to the construction of a patrol cabin by the U.S. Forest Service in 1910 near the mouth of Berry Creek. The 1949 GTNP Building Survey identifies the (first) Berry Creek Patrol Cabin as Building No. 61 (See Figures $1 \& 2$ ). It is described as one room, one story, measuring $8 \times 20$ feet, 144 square feet (perhaps they did not count the porch, which in some photographs is fitted with screening material). The building survey claims the cabin was built in 1910 , and remodeled in 1938. Beginning around 1910, both the Bureau of Reclamation and the U.S. Forest Service began to string phone lines in the area. A telephone line was installed connecting Berry Creek to another cabin further up the drainage, and perhaps the fire lookout station at "Point A." This phone line also may have extended from Berry Creek Cabin eastward across the Snake River to the highway. Control of fires was a top priority in forest management, with the prevention of timber trespass closely following. The Berry Creek Cabin, listed in some documents as a "fireguard cabin," facilitated those functions in the northwest portion of

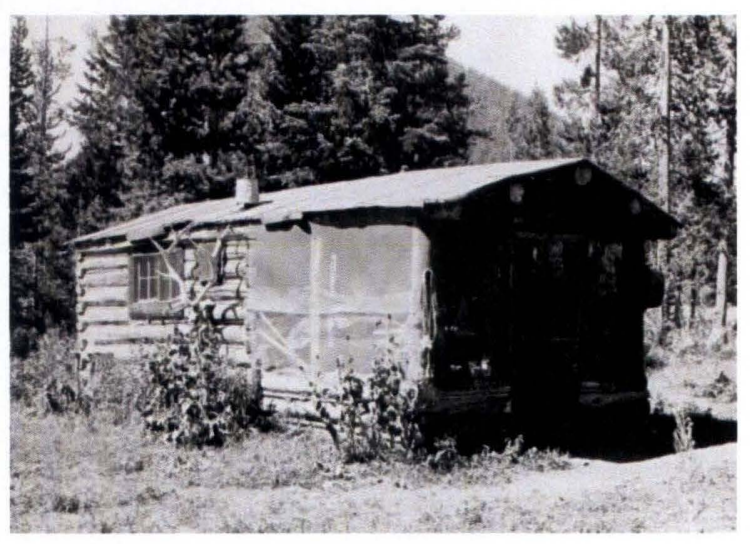

Teton National Forest (See Figure 3).

Figure 1. The original Berry Creek cabin, Building No. 61 . Probably built by the USFS in 1910. GTNP Archives.

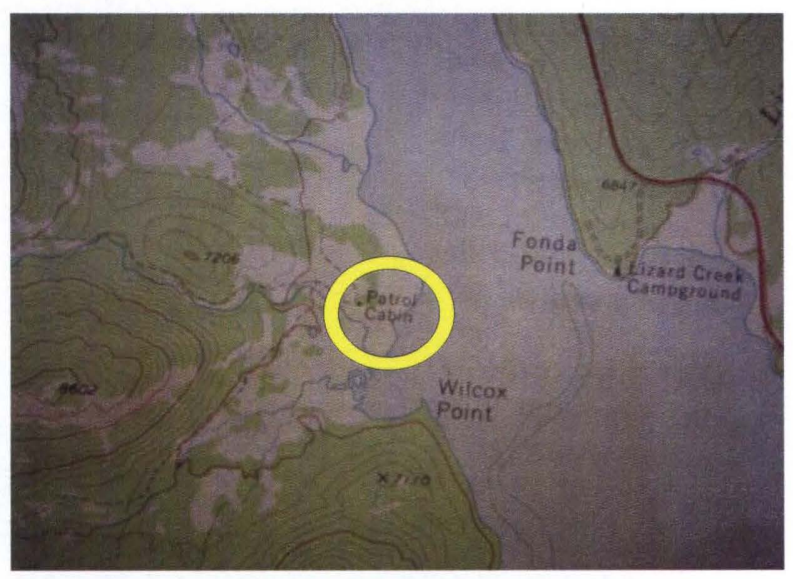

Figure 2. 1968 USGS map showing north end of Jackson Lake and the location of the Berry Creek Patrol Cabin near the mouth of Berry Creek. GTNP Archives. 


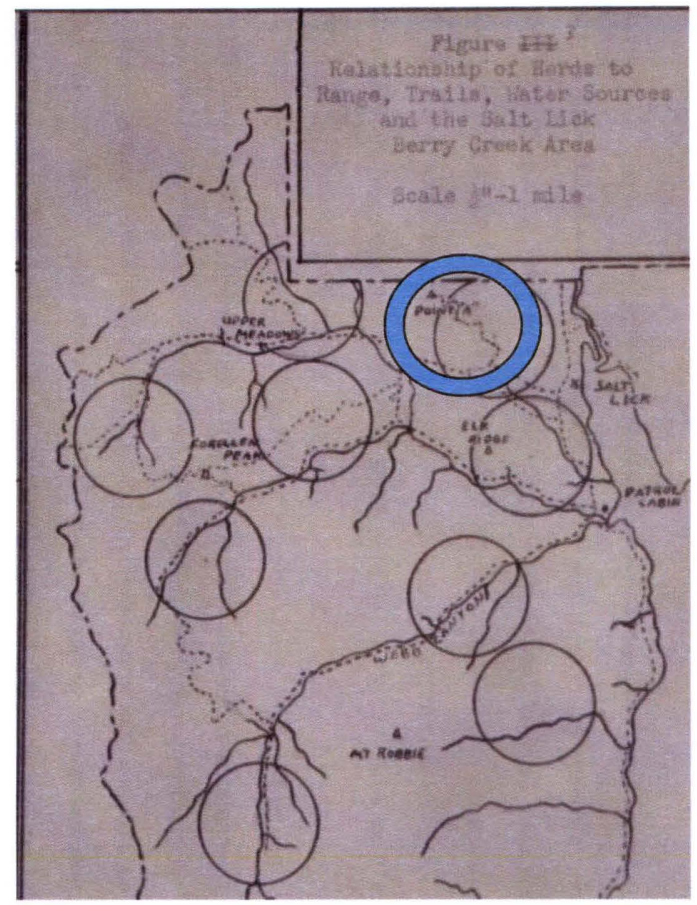

Figure 3. A rare clue to the location of the fire lookout at "Point A," used by the USFS and later the NPS in fire control activities, is found in this 1959 map by elk researcher Neil G. Guse, who noted only the lower Berry Creek cabin. GTNP Archives.

In 1943, management of the cabin passed from the U.S. Forest Service to the National Park Service, with the establishment of the Jackson Hole National Monument. Despite the 1938 repairs, a 1949 building survey (just before the expansion of Grand Teton NP) described the condition of the Berry Creek Cabin as "poor." In 1956, GTNP officials decided to replace the structure. The best available evidence indicates that the Berry Creek Cabin was moved from the Feuz Ranch on Spread Creek to its present location. One might wonder if moving a log cabin was worth the time and energy, but actually buildings of various sizes in the parks have been moved with good effect, employing various strategies and methods (see Figure 4).

The Feuz family ranch was one of the properties involved in the expansion of Grand Teton National Park. Gottfried ("Fred") Feuz had departed Switzerland after he was caught poaching a deer. The penalty was 500 francs, a year in prison, or a promise to permanently emigrate. After a brief sojourn in Idaho, Fred brought his wife Caroline and two young daughters over Teton Pass into Jackson Hole, where he staked a claim on Spread Creek. The family ran a successful cattle ranch on this site from 1914 to 1953.
Fred was an excellent hunter, and even during the Depression the family had enough to eat. He worked on and off with the Forest Service, and started guiding hunting clients around Mt. Leidy. The family was not interested in the offers of the Snake River Land Company to purchase their property. In 1943, the Jackson Hole National Monument was created by Executive Order. At this time, the family still refused to sell. Caroline Feuz recalled that "[finally] we were given a choice of either our property being confiscated, or trading for other land. The land they had in mind was bordering the edge of the park near our son Walt's ranch. So we accepted this offer. The Park Service eventually had all our buildings and fences removed and burned" (Nielsen 1988).

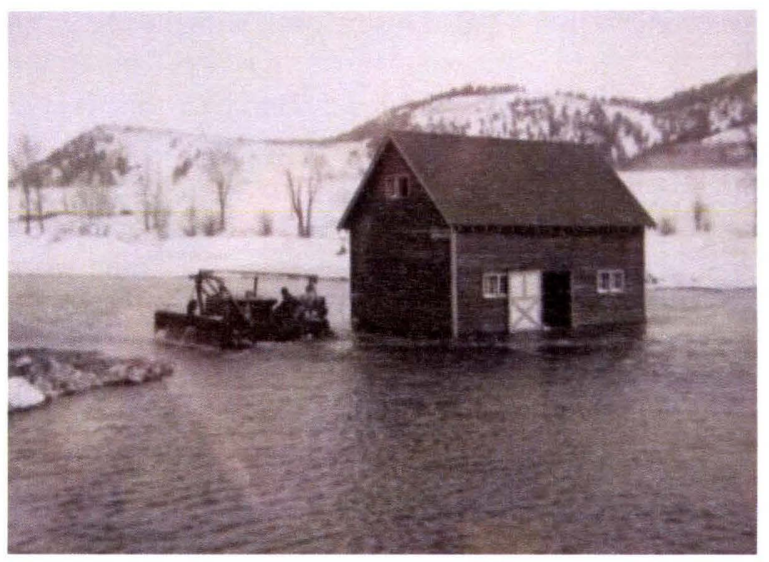

Figure 4. It was not unheard of for structures to be moved to a new site. Moving barn from Gros Ventre Ranger Station to Grand Teton National Park Headquarters, 1955. GTNP Archives.

Two sources of information support the claim that today's Berry Creek Cabin was moved to its present site in 1956. The GTNP Superintendent's monthly report for July, 1956, stated "A log cabin was erected at the Berry Creek Ranger Station. Window screens were constructed at the Johnson residence" (Box 201, NARA). This rather brief description is mentioned under the category of maintenance/ trails, not plans and construction. No further details were found in attached budgets and work program listings, or in separate reports of design and construction filed with monthly reports. The "Johnson residence" may have referred to the site of today's University of WyomingNational Park Service Research Station (AMK Ranch) near Sargents Bay on the east side of Jackson Lake, where the Johnson family had maintained a summer home until 1937 when Alfred and Madeline Berolzheimer bought the property (Park 2000). 
The best source supporting this narrative came from the person who organized the dismantling and reassembly of the cabin, $\log$ by $\log$. In 1995 , while preparing a National Register multiple property submission for GTNP, historians interviewed Doug McClaren, a former North District ranger (See Figure 5). This interview was fortuitous, as he later passed away. McClaren related how he and other park employees (most probably from the ranger division and from the trail crews) disassembled a cabin standing at the Feuz Ranch near Spread Creek. They floated the logs across Jackson Lake and moved them onto or near the site of the existing cabin, which they tore down. McClaren and his team reassembled the logs into the structure we see today, measuring about 15 by 13 feet of interior space. McClaren's recollection was that this occurred around 1950. This fits well with the comment in the 1956 Superintendent's report regarding construction of a cabin at lower Berry Creek. GTNP archives contain a photograph of the Berry Creek Cabin after construction (See Figure 6). To the side lie several concrete blocks closely resembling foundation piers found on site today. McClaren's account rings true. Floating logs across Jackson Lake was not exceptionally difficult; during the 1990 s, the cabin at Moran Bay was renovated using this approach. Additionally, the timing of moving the cabin fits the history of the Feuz Ranch, as the parcel was sold to the Jackson Hole Preserve between 1947 and 1949, and the park superintendent reported in 1959 that all buildings had been removed.

In 1978, ranger Jim Bell installed a logbook in the Berry Creek Cabin. Reading this anecdotal account of 30 years of park staff visits gives the sense that a cabin is not simply constructed in a particular year, to endure unchanged for decades. Very much like a trail, a cabin requires continual care and maintenance. Logbook entries reveal that in 1989 the corral was reconstructed, in 1990 a wood stove was flown down from Upper Berry and installed, and in 1992 interns from the Student Conservation Association renewed the linseed oil finish on the exterior log surfaces. A sheet metal roof was added to the Lower Berry Cabin, most probably around 2005 , partly in response to the 2000 forest fire on the west side of Jackson Lake that destroyed the Moran Bay Patrol Cabin. Metal roofs make buildings easier to defend during a fire event (See Figure 7).

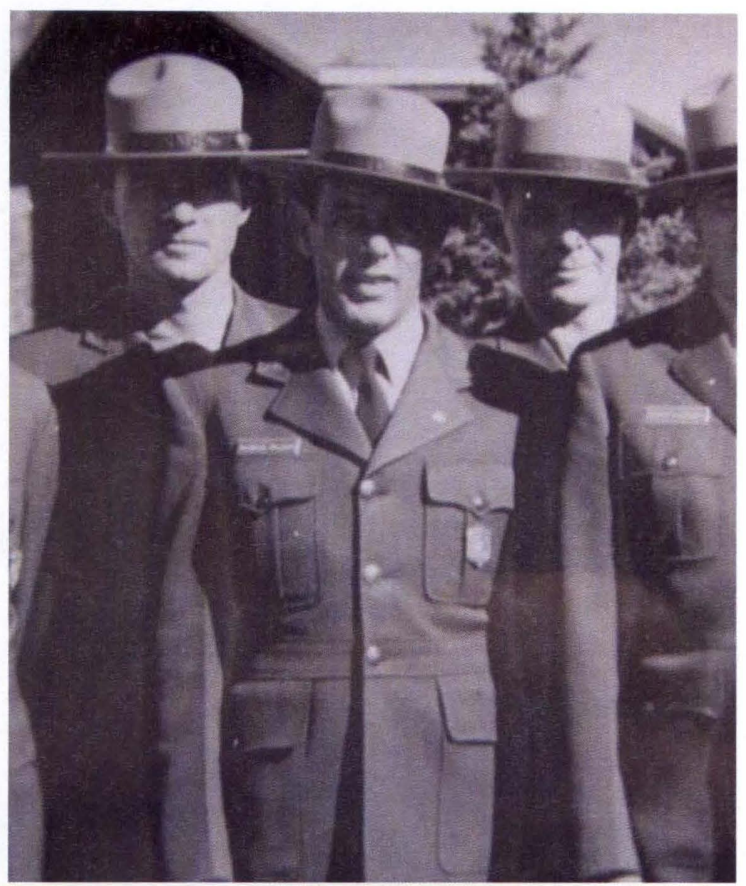

Figure 5. Grand Teton National Park Rangers George Wagner, Doug McLaren, and John Higgins. GTNP Archives.

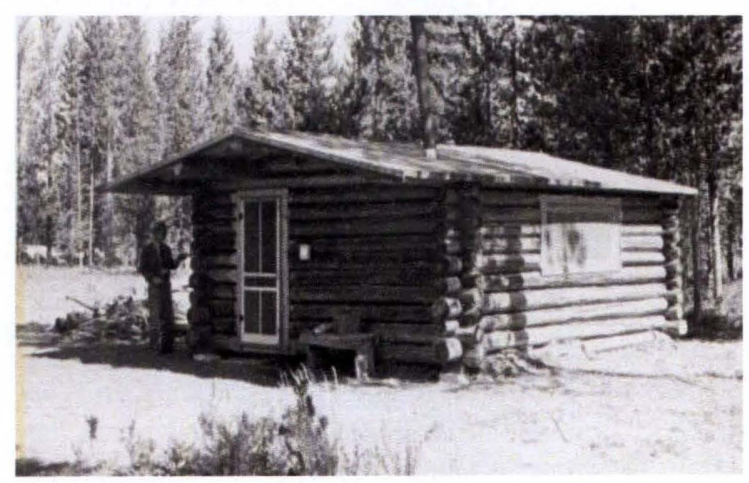

Figure 6. (Lower) Berry Creek Cabin after construction, c. 1956. GTNP Archives.

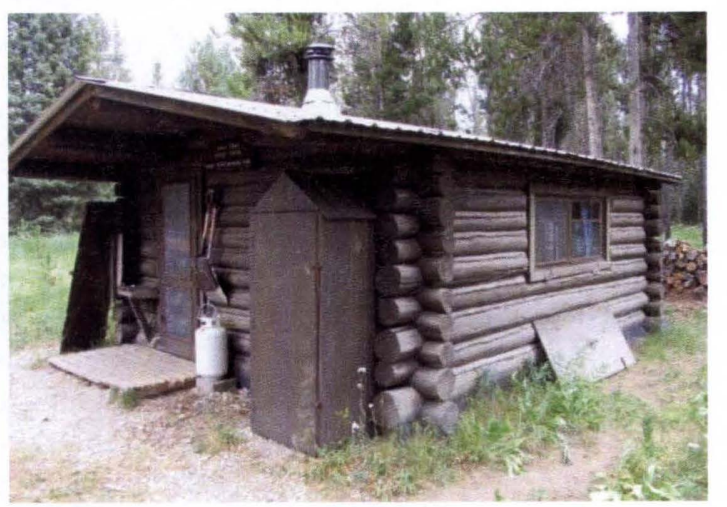

Figure 7. (Lower) Berry Creek Patrol Cabin in 2007. Photo James Pritchard. 
In a tragic bit of history, Park Ranger John C. Fonda (28) and District Ranger Gale Wilcox (48) died on March 9, 1960, as legend has it while traveling to Berry Creek Cabin. They were crossing the Snake River on cross-country skis, when the ice broke under them. The Assistant Chief Ranger also fell into the water as he tried to help, managed to drag Ranger Wilcox from the river, and set out to seek assistance. When rescuers arrived, Wilcox had already expired. The Former Lizard Point on the east side of Jackson Lake nearby was renamed Fonda Point, and on the west side of the lake the point of land just south of Webb and Berry Creeks was named Wilcox Point (Nielsen 1988).

\section{Lower Berry Creek Patrol Cabin's Suitability for the National Register.}

During a 1997 survey of park structures, Historic Research Associates recommended a reevaluation of the Berry Cabin when it attained 50 years in service as a National Park Service administrative site. Since Berry Creek Cabin was reconstructed on site in 1956, it has functioned in its present place for 52 years, and therefore is eligible for inclusion on the National Register based on age, if it meets other thematic criteria (Longfield 2008).

Criteria A (Association with Grand Teton National Park Administration and Development) has provided a fundamental rationale of significance for listing other GTNP backcountry cabins on the National Register of Historic Places (including Sweet Grass Ranger Station, Moran Bay, and Leigh Lake patrol cabins). The Berry Creek Cabin fits Criteria A very well, because a patrol cabin on this site has proved vital to the administration of public lands beginning with the creation of Teton National Forest. The lower Berry Creek site has a long period of function in park administration, since at least 1943 when the Jackson Hole Monument was created by Executive Order. Even before 1943, the Forest Service evidently allowed National Park Service personnel to use the cabin at Berry Creek. During the 1950s, the designation "Ranger Station" appears on some documents, inferring an enhanced administrative function for the Berry Creek Cabin.

The system of backcountry patrol cabins has proved essential to resource management at Grand Teton National Park. During the inception of Grand Teton NP, Superintendent Woodring placed the creation of a trail system at the top of his list. It is clear that the backcountry cabins have facilitated the operation of trail crews and rangers as they constructed and cleared trails. Just as importantly, the National Park Service faced the same challenges as the U.S.
Forest Service, that is to say how to patrol the administrative boundaries of a relatively remote area against timber, hunting, grazing, and (later) motorized vehicle trespass.

The Lower Berry Cabin exemplifies several aspects of the "Rocky Mountain Cabin" architectural style, a significant vernacular form originally arising out of practicality, but today exuding western myth and imagination. As Jim Bailey pointed out in his wonderful study of architecture in the Bridger-Teton National Forest, the roots of the style actually came from Finnish immigrants building cabins on the Great Plains. The Rocky Mountain Cabin style, Bailey noted, "is distinguished by a square or rectangular single-cell floor plan, horizontal log construction with squarenotched ends, a lack of decoration, a front-facing gable, a single door offset in the gable end, roof slopes under 45 degrees, a preference for iron stoves over fireplaces, and the front gable end of the roof extending an average of 50 percent beyond the cabin's front gable elevation" (Bailey 2003.). The Berry Creek Cabin diverges from the Rocky Mountain Cabin style mainly in its use of saddle-notched logs.

Ann Hubber and Janene Caywood noted that vernacular architecture preceded the Rustic style in Grand Teton National Park. Pioneer vernacular was "a practical response to environmental and economic dictates while formal Rustic architecture represented the deliberate attempt - usually an architect's deliberate attempt - to convey historical images and to meld manmade resources with their wilderness environment" (Hubber 1997) (Hubber and Caywood, 1997; See also McClelland; USFS; Wilson). Some cabins in GTNP seem to fit in with the Rustic style, such as the Ranger's Station at Jenny Lake, or the Sweetgrass Ranger Station. Nestled into its remote setting, the simple patrol cabin at Berry Creek better fits the vernacular "Rocky Mountain Cabin" style.

\section{The Cabins at Survey Peak, Moose Basin, and Upper Berry Creek}

An intriguing search for the origins of two small shelter cabins in the northwest part of GTNP revealed that beginning with trappers and miners, various cabins have been constructed in the Owl and Berry Creek drainages. Cabin No. 279, the Survey Peak cabin, most probably was located northeast of today's Upper Berry cabins, between Survey Peak and Point 8775 (See Figure 8). It was built some time before 1949, when it appears on a USGS map, and was razed in 1962 after damage caused by heavy snow loading. The U.S. Forest Service might have 
constructed this cabin, as a later USFS map depicted a "F.S. Patrol Cabin" in this vicinity (See Figure 9).

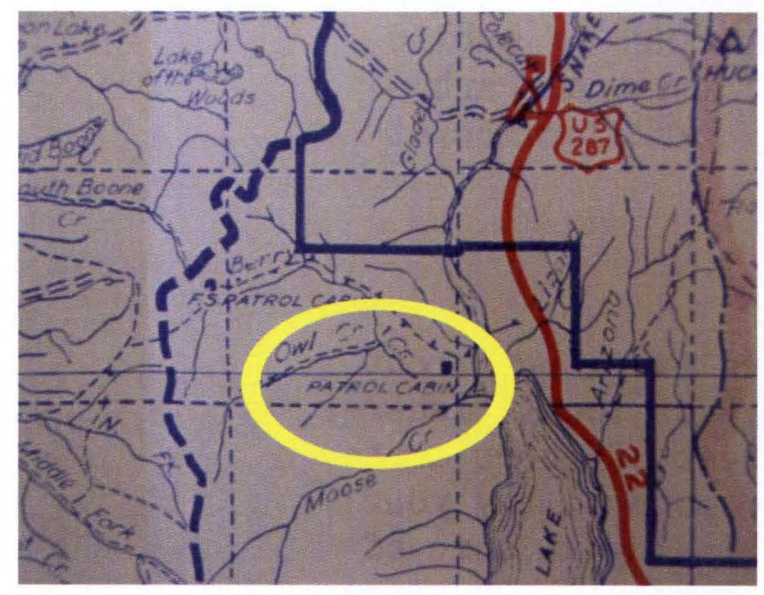

Figure 8. 1949 USGS map showing a structure near the pass between Survey Peak and Point 8775 . This was probably the Survey Peak Cabin (Building \#279). The map also shows a structure in Upper Berry Creek, at the trail juncture next to the elevation 7558. This clue indicates that the small cabin may well predate the commonly assumed early 1960s. GTNP Archives.

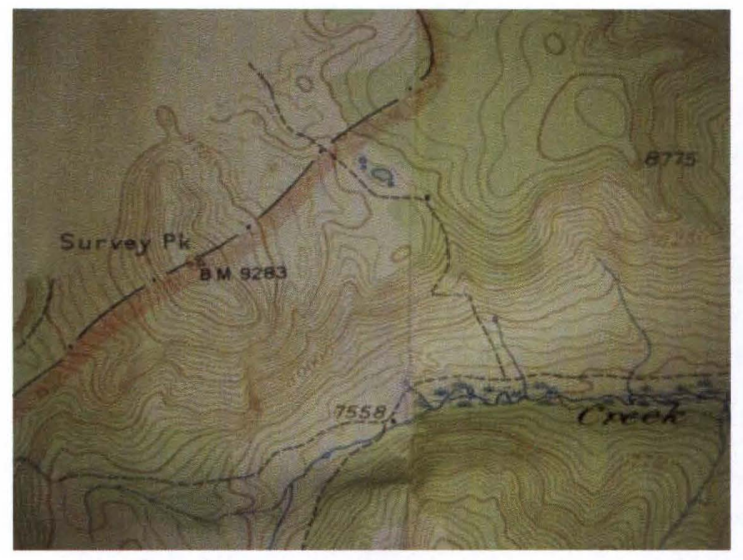

Figure 9. This Forest Service map (curiously dated 1956) depicts a "F.S. Patrol Cabin" in Upper Berry Creek, as well as a phone line between the patrol cabins.

Backcountry management documents for GTNP suggest that small (about 14 by 12 feet on the exterior) shelter cabins were built at Moose Basin and at Upper Berry Creek as part of an elk study during the early 1960s (See Figure 10). Local legend has it that Olaus Murie was involved with the construction of these cabins. Murie worked as a field biologist for the Bureau of Biological Survey and its successor the Fish and Wildlife Service from 1920 until 1946. He arrived in Jackson's Hole in 1927 when he was assigned a study of the elk herds of the region, during the golden days of horse-packing. Born in 1889, Olaus was 75 when he died in 1963. It seems doubtful he would have been constructing shelters in the backcountry, much less using prefabricated materials, given his clearly expressed opposition to overt and unnecessary manipulations within the national parks.

So far, we have found no documentary evidence to support the notion that Olaus Murie constructed cabins in the North District. This idea may have its origins in the fact that from 1951 to 1953 , Adolph Murie (Olaus's brother) served as Grand Teton National Park's biologist, working on (among other things) elk migration studies. Park naturalists Howard Stagner and Carl E. Jepson also conducted elk migration studies during the $1950 \mathrm{~s}$, but mostly on the eastern side of Jackson Lake. In 1959, Neil G. Guse summarized a two year study in the Berry Creek area, but did not mention any cabins in the high country used in elk migration studies (See Figure 3).

There is a possibility that these small cabins (See Figure 10) could have been built as early as the mid-1930s, when a similar structure was erected on the western shore of Jackson Lake. Building No. 49, the "Hot Springs" patrol cabin on the west shoreline of Jackson Lake, was constructed in 1935 and remained standing in 1949. The similarity of the board and batten style of the exterior walls of the three small cabins at Upper Berry, Moose basin, and Hot Springs appears striking.

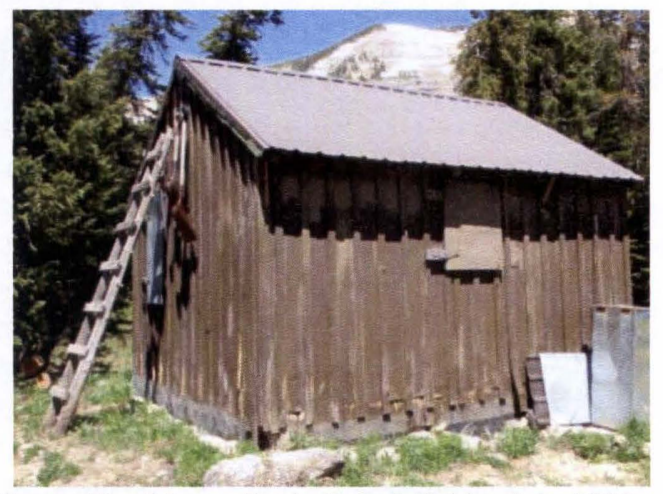

Figure 10. Moose Basin Patrol Cabin, July 2008. Photo James Pritchard.

Logbooks kept at Moose Basin cabin confirm that materials for improving an existing cabin were flown in on September 18, 1980, when Ranger Jim Bell reported "a glorious day for Moose Basin. The Army in a Chinook helicopter flew in the materials to insulate, panel and put in a new floor." In 1987, the small shelter cabin at Upper Berry was converted to storage purposes when a handsome new cabin was constructed. Logs and other construction materials were transported to the site using a helicopter from Yellowstone, where 
Al Williams (of the trail crew) supervised a construction crew from the Student Conservation Association. In 2005, rotting sill logs on the new patrol cabin were replaced.

\section{$+\quad$ CONClusions}

Given its age, its unique history in the park, its administrative function and facilitation of patrolling the remote North District, and its fit with the Rocky Mountain Cabin style, it is time for the Lower Berry Patrol Cabin to join other backcountry patrol cabins of Grand Teton National Park on the National Historic Register. More research is required to unveil the exact origins of the other original cabins in the North District, located at Moose Basin, Upper Berry Creek, and Survey Peak.

\section{$\downarrow \quad$ RESEARCH SOURCES}

Grand Teton National Park Archives.

NARA: National Archives and Records Administration, College Park, Maryland. Record Group 79, Entries 10 $\& 11$.

Jackson Hole Historical Society, Jackson, Wyoming.

Bridger-Teton National Forest Archaeologist's Office, Jackson, Wyoming.

\section{$\downarrow$ Literature Cited}

Bailey, J. 2003. "Lookouts, Latrines, and Lodgepole Cabins: Administrative Facilities of Wyoming's Bridger-Teton National Forest, 1904-1955." (Two Volumes, Forest Service Report No. BT-02-637), USDA FS Intermountain Region, Bridger-Teton National Forest.

Daugherty, J. 1999 A Place Called Jackson Hole: The Historic Resource Study of Grand Teton National Park. Moose, WY: Grand Teton National Park.

Grand Teton National Park. 2000 "Management Plan for the Buildings Listed on the National Register of Historic Places." February.
Historical Research Associates. 1997. "Draft Historic Building/Structure Survey Form" GTNP Archives.

Hubber, A. and J. Caywood. 1997. "Survey Report of Selected Historical Cultural Resource Properties Located Within Grand Teton National Park, Wyoming" GTNP Archives.

Longfield, K. and J. Pritchard. 2008. Nomination to National Register of Historic Places, Lower Berry Patrol Cabin.

McClelland, L.F. 1998. Building the National Parks: Historic Landscape Design and Construction. Baltimore: Johns Hopkins University Press.

Nielsen, C. 1998. Origins: A Guide to the Place Names of Grand Teton National Park and the Surrounding Area. Moose, Wyoming: Grand Teton Natural History Association.

Righter, R. 1982. A Crucible for Conservation: The Creation of Grand Teton National Park. Boulder: Colorado Associated University Press.

U.S. Forest Service. 2003 "Historic Context Statement," Part Two, Architectural History. U.S. Forest Service, Region 4, 17.

Williams, L.F. 2002. "Feuz Family History.” Jackson Hole Historical Society Acc. \#2003.0121.002,

Wilson, R. 2004. "Within a Day's Ride: Forest Service Administrative Sites in Region 4, 1891-1960." United States Forest Service. Online at www.fs.fed.us/r4/publications/pubs/r4_admin_sites _history_evals.pdf.

\section{$\downarrow$ FURTHER INFORMATION}

Readers can find out more about the cabins, the context of park history, and a sense of the treasure hunt involved in historical research by viewing the complete report, available from www.public.iastate.edu/ jpritch. 